\title{
OGRANICZENIA ROZWOJU SOCJOLOGII KRYTYCZNEJ. PRÓBA ALTERNATYWNEGO WYJAŚNIENIA ${ }^{1}$
}

Mikołaj Pawlak

Uniwersytet Warszawski

\section{/// Wprowadzenie}

Tomasz Warczok i Tomasz Zarycki w opublikowanym w „Stanie Rzeczy" artykule pt. (Ukeryte) zaangażowanie i (pozorna) neutralność. Strukturalne ograniczenia rozwoju socjologii krytycznej w warunkach pótperyferyjnych (2014a) postanowili wyjaśnić, dlaczego socjologowie w Polsce nie angażuja się w demistyfikację relacji władzy. Ich zdaniem wynika to z zależności pola socjologicznego od pola władzy oraz od peryferyjnego położenia Polski, w której inteligencja - klasa dysponująca kapitałem kulturowym - nie ma obecnie interesu w podważaniu status quo. Tekst ten stawia wiele ciekawych tez, słusznie upomina się o stosowanie wyjaśnień strukturalistycznych, a nie indywidualistycznych w socjologii oraz w ciekawy, charakterystyczny dla twórczości Zaryckiego sposób pokazuje pozycję inteligencji w dzisiejszej Polsce.

Uważam artykuł Warczoka i Zaryckiego za zarazem uwodzicielski i zwodniczy. Celem niniejszego tekstu jest ujawnienie ukrytych założeń autorów, ich strategii argumentacyjnej oraz konsekwencji tych założeń i argumentacji dla obrazu pola socjologicznego. Zamierzam pokazać, jak autorzy, działając strategicznie, demistyfikują relacje władzy, ale równocześnie inne

\footnotetext{
${ }^{1}$ Niniejszy tekst został napisany na podstawie wystąpienia wygłoszonego 12 grudnia 2014 r. podczas debaty Oddziału Warszawskiego Polskiego Towarzystwa Socjologicznego i czasopisma „Stan Rzeczy” pt. „Nauki społeczne w pułapkach zaangażowania - krytyczna konfrontacja”. Chciałbym podziękować uczestnikom debaty, których głosy w dyskusji wpłynęły na jego ostateczny kształt. Oddzielne podziękowania składam dr Iwonie Zielińskiej za krytyczne uwagi do wstępnej wersji tej pracy.
} 
relacje władzy ukrywają. Odnoszę się przede wszystkim do wspomnianego artykułu o strukturalnych ograniczeniach rozwoju socjologii krytycznej (Warczok, Zarycki 2014a), ale również sięgam do będącego jego dopełnieniem artykułu na temat użyć koncepcji kapitału kulturowego w polskiej socjologii (Warczok, Zarycki 2014b). Niniejszy tekst mieści się, w moim zamierzeniu, w socjologii krytycznej, tak jak zdefiniowal ja Michael Burawoy (2009), a poprzez krytykę pracy Warczoka i Zaryckiego przedstawia alternatywne wyjaśnienie dla ograniczeń jej rozwoju w Polsce. Przyczyny jej słabości dostrzegam przede wszystkim w ograniczeniach socjologii akademickiej, będącej dla pozostałych typów socjologii podstawą.

Mój wywód ma następujący porządek. Rozpoczynam od przestawienia założeń przyjętych przez Warczoka i Zaryckiego, a następnie analizuje ich rekonstrukcję pola socjologicznego w Polsce. Kolejnym krokiem jest zaproponowanie alternatywnego zestawu założeń, pozwalającego, moim zdaniem, dokonać trafniejszej rekonstrukcji pola. Na tak przygotowanym gruncie dokonuję interpretacji pracy Warczoka i Zaryckiego jako działania strategicznych aktorów w polu - jest to próba socjologii socjologii socjologii, w której wskazuję na pułapki zwrotności czyhające na badaczy pola, do którego przynależą. Następnie w oparciu o koncepcję czterech typów socjologii Burawoya (2009) wskazuję, że przyczyny ograniczeń socjologii krytycznej leżą we wzajemnych relacjach pomiędzy tymi czterema typami. Całość zamyka konkluzja, w której występuję przeciwko socjologii eseistycznej ${ }^{2}$.

\section{/// Założenia przyjęte przez Warczoka i Zaryckiego}

Warczok i Zarycki przyjmują założenie, że świat jest takim, jak opisał go Pierre Bourdieu, i według jego wskazówek źródeł praktyk symbolicznych poszukują w konfiguracjach strukturalnych (2014a: 130). W bibliografii liczącej 74 pozycje 23 to teksty Bourdieu. Odwołania do Bourdieu i jego wizji społeczeństwa są traktowane jako rozstrzygnięcia wszelkich dylematów zarówno dotyczących teorii, jak i celu uprawiania socjologii oraz traktowania danych empirycznych.

Kluczem do analizy kondycji socjologii krytycznej jest odtworzenie pola socjologicznego i jego relacji z innymi polami. Za Bourdieu pole społeczne jest przez Warczoka i Zaryckiego rozumiane jako obszar spo-

\footnotetext{
2 Zdaję sobie sprawę, że w tym tekście częściowo zawarte są moje intuicje oraz postawione są pytania, na które nie udzielam odpowiedzi, więc „zarzut eseistyczności” mógłby zostać także skierowany przeciwko mnie.
} 
łecznych zmagań, w którym podstawowym podziałem jest rozróżnienie na dysponujących nierówną ilością kapitału symbolicznego dominujących i zdominowanych. Pola społeczne tkwia we wzajemnych powiązaniach oraz odtwarzają dychotomie panujące w polu władzy. W polskim polu władzy zasadniczy jest podzial na stanowiska pro- i antycentrowe ${ }^{3}$, czyli modernizacyjne i narodowe. Taki podział, zdaniem Warczoka i Zaryckiego, charakterystyczny jest dla społeczeństw peryferyjnych (2014b).

Kolejnym ważnym odniesieniem dla pracy Warczoka i Zaryckiego jest koncepcja socjologii krytycznej. Tutaj sprawa jest nieco bardziej skomplikowana, gdyż pojęcie to jest używane przez nich w dwóch odmiennych znaczeniach. Po pierwsze, odwołują się do typologii Burawoya, dla którego socjologia krytyczna to ,analiza założeń programów badawczych realizowanych w ramach socjologii akademickiej - zarówno jawnych, jak i ukrytych, normatywnych, jak i deskryptywnych" (2009: 535). Po drugie, za Bourdieu przyjmują, że socjologia krytyczna „ma na celu demistyfikację istniejących relacji władzy" (Warczok, Zarycki 2014a: 129).

Poza socjologią krytyczną Burawoy wydziela jeszcze socjologię akademicką, praktyczną i publiczną (2009). Warczok i Zarycki koncentrują się przede wszystkim na socjologii publicznej, w zasadzie nie interesując się socjologia akademicką, a socjologia praktyczną wręcz pogardzając, nazywając ją także służebną ${ }^{5}$.

\section{/// Rekonstrukcja pola socjologicznego}

Warczok i Zarycki dokonują bezlitosnej rekonstrukcji polskiego pola socjologicznego. Zaznaczyć trzeba przede wszystkim, że czytelnicy nie otrzymuja informacji, na jakiej podstawie pole to zostaje przedstawione. Praca (Ukryte) zaangażowanie i (pozorna) neutralność (Warczok, Zarycki 2014a) nie zawiera części prezentującej warsztat zbierania danych ani procedurę ich analizy. Z artykułu Bourdien recontextualized (Warczok, Zarycki 2014b) dowiadujemy się, że autorzy dokonują studium przypadku stosowania

\footnotetext{
3 Termin „centrum” ma tu znaczenie zaproponowane przez Wallersteina (1974).

${ }^{4}$ Można odnieść wrażenie, że Warczok i Zarycki przypisują Burawoyowi to drugie rozumienie pojęcia socjologii krytycznej. W koncepcji Burawoya demistyfikacja relacji władzy jest raczej jednym z zadań socjologii publicznej. W niniejszym tekście, aby nie „ślizgać” się pomiędzy tymi różnymi znaczeniami, będę stosował termin „socjologia krytyczna” w rozumieniu Burawoya, natomiast w rozumieniu Bourdieu będą nazywał ją socjologia demaskatorską - przywołując koncepcję pięciu funkcji socjologii zaproponowaną przez Adama Podgóreckiego (1966).

${ }^{5}$ Epitet „służebna” dodany jest przez Warczoka i Zaryckiego (2014a). Burawoy konsekwentnie używa terminu ,socjologia praktyczna” (w jęz. angielskim policy sociology), służebność traktując jako jej możliwą patologię (2009).
} 
bourdiańskiej koncepcji kapitału kulturowego w polskim polu socjologicznym. Jednak i tam nie jest przedstawiony sposób doboru tekstów do analizy. Pytanie: czy Warczok i Zarycki przeczytali wszystkie prace, stosujące tę koncepcję (co byłoby prawdopodobnie olbrzymim przedsięwzięciem), czy stosowali jakąś procedurę doboru, a może po prostu wybrali kilka tekstów na chybił trafił - pozostaje otwarte.

Warczok i Zarycki nie podaja również kryteriów, według których wygłaszaja pewne diagnozy dotyczące pola socjologicznego i jego relacji z innymi polami. Pole socjologiczne ich zdaniem „odznacza się dość słabą autonomią, ale jednak jest „relatywnie odseparowane od pozostałych pól” (Warczok, Zarycki 2014a: 136, 148). Nie dowiadujemy się, jaka jest stosowana przez autorów miara owej autonomii ani do autonomii jakich innych pól ją porównują. „Większość jej przedstawicieli [elity pola socjologicznego], korzystając ze swojej uprzywilejowanej roli inteligenckich autorytetów, podejmuje pracę równocześnie w kilku różnych instytucjach" (tamże: 132) - jednak znowuż nie wiemy, czy jest to wiedza potoczna uczestników pola, czy wynik analizy danych dotyczących zatrudnienia socjologów. „Znacząca liczba polskich socjologów, a również innych naukowców społecznych [...] należy do grona gwiazd medialnych pojawiających się regularnie zarówno na łamach prasy drukowanej, jak i mediów elektronicznych [...], i maja [medialni socjologowie] wymierny wpływ na życie społeczne i polityczne w Polsce" (tamże: 137) - tutaj również nie jest jasne, co to znaczy „znacząca liczba” (w porównaniu z innymi polami naukowymi w Polsce?), ale przede wszystkim pozostaje niejasne, na czym polega ów „wymierny” wpływ na życie społeczne.

W polskim polu socjologicznym pozycje zajmują ortodoksi tacy jak Piotr Sztompka, Henryk Domański i Mirosława Marody. Przeciwstawieni są im heterodoksi - Andrzej Zybertowicz, Zdzisław Krasnodębski i Jadwiga Staniszkis. Wskazanie kluczowych graczy pola przyjęte jest według kryterium obecności w mediach oraz ,ze względu na posiadany kapitał naukowy" (tamże: 148). Jednak również czytelnik nie poznaje miary kapitału naukowego. Należy bądź zawierzyć trafności wyboru autorów, bądź przyjąć, że miara ta jest oczywista. Nie dowiadujemy się również nic o tym, jakie pozycje w polu socjologicznym zajmuja tak zwani „zwykli socjologowie” ani ci wszyscy, którzy uprawiają socjologię, nie bywając na „medialnych salonach".

Pole socjologiczne odtwarza podziały pola władzy i bliskiego mu pola medialnego, w którym pojawiają się socjologowie opisywani przez autorów. W związku z tym w polu socjologicznym mamy spór między procen- 
trowymi modernizatorami a antycentrowymi eurosceptykami denuncjującymi zwycięzców transformacji. Ortodoksi „nieświadomie” legitymizują nierówności w Polsce. Przyjęte przez nich teorie noszą znamiona skrzywienia mentalistycznego (tamże: 143), czyli wyjaśniają sytuację przegranych transformacji nie ich zdominowana pozycja w strukturze społecznej, lecz ich cechami jednostkowymi, takimi jak "cywilizacyjna niekompetencja” (Sztompka 1993), „socjalistyczne rezydua” (Marody 1991) itp. Heretycy jednak nie dokonuja prawdziwej krytyki - w sensie demistyfikacji istniejących relacji władzy - lecz tłumacza „,społeczne zło przez aktywność określonej grupy ludzi" (Warczok, Zarycki 2014a: 150).

Warczok i Zarycki najbardziej zawzięcie atakuja Henryka Domańskiego, który ich zdaniem, „nie wyjaśniając strukturalnego ich [nierówności] efektu, akcentując wymiar indywidualny, w rezultacie legitymizuje naukowo istniejący układ” oraz „dokonuje niewypowiedzianej legitymizacji nierówności (funkcje mają służyć systemowi jako takiemu). W efekcie bezrefleksyjnie przyjmowany neoliberalizm łączy się doskonale z podstawowymi założeniami strukturalnego funkcjonalizmu oraz ewolucjonizmu teorii modernizacji” (tamże: 145-146). Stwierdzenie to należy uznać jednak za nadużycie. W poddanej przez autorów analizie wypowiedzi Domański otwarcie, a nie w sposób niewypowiedziany, sankcjonuje funkcjonalny charakter nierówności, jednak jego wyjaśnienia są stricte strukturalistyczne: postawy jednostek są pochodną ich pozycji w strukturze społecznej! Sądzę, że można być liberałem (celowo usuwam tutaj używany niekiedy jako obraźliwy przedrostek „neo”) w sposób świadomy.

Z takiej rekonstrukcji pola Warczok i Zarycki wyciagają wnioski o strukturalnych przeszkodach rozwoju myślenia krytycznego wobec istniejących relacji władzy. Może ono rozwinąć się jedynie w autonomicznym polu socjologicznym. Obecnie zdaniem autorów pole owej autonomii jest pozbawione, więc socjologowie skazani są na wpisywanie się w dychotomię pro-/antycentrowa. Jednak w jednym z przypisów autorzy dokonuja auto-socjo-analizy, którą warto przytoczyć tutaj w całości:

Sytuujemy się zatem raczej na pozycjach strukturalnie zdominowanych w polu, jednak ze względu na brak realnych powiązań politycznych i oddalenie od pola medialnego pozostajemy relatywnie odseparowani od symbolicznej dychotomii pro-centrum/centrosceptycyzm. Najbliższa jest nam, co nie powinno być żadnym zaskoczeniem, socjologia krytyczna, która w zarysowanym układzie sytuowałaby się pośrodku przywołanego podziału strukturalnego, 
czyli w miejscu raczej niepewnym, bo dopiero wykuwanym. Nasze relatywne nieuwikłanie w dominujący podział wynika także $z$ faktu, iż nie jesteśmy trwale związani z żadną lokalną ,szkołą” bądź „ośrodkiem”. Oczywiście, korzystając z teorii Bourdieu, wypracowanej przecież w obszarze centrum, jesteśmy od niej symbolicznie zależni, jednak staramy się koncept francuskiego socjologa przepracowywać przez samo doświadczenie (pół)peryferii. Zgodnie więc z zasada, do której sam Bourdieu zachęcał, jesteśmy „z i przeciw” Bourdieu (tamże: 150-151).

Czyli jednak Warczokowi i Zaryckiemu, mimo okowów strukturalnych, udaje się uzyskać nieco swobody i dzięki temu są w stanie uprawiać socjologię krytyczna, co swoim tekstem czynią. Zauważmy jednak, że jako dyrektor Instytutu na Uniwersytecie Warszawskim jeden z autorów dysponuje relatywnie dużym jak na pole socjologiczne dostępem do władzy, a jego imponujący spis publikacji świadczy również o zgromadzonym sporym kapitale naukowym.

Podsumowując, relacje w polu socjologicznym to relacje pomiędzy modernistycznymi ortodoksami i antycentrowymi heterodoksami. Odtwarzają one relacje w polu władzy poprzez powiązania z nim i zależnym od pola władzy polem medialnym. Autorzy nie wyjaśniaja jednak mechanizmu owej strukturacji pola socjologicznego powielającej strukturę pola władzy. Przyjmuja za oczywiste za Bourdieu, że tak musi być. Podobnie nie dokonują własnej analizy polskiego pola medialnego ani nie korzystaja $z$ istniejącej na jego temat literatury, lecz do jego opisu stosują analizy Bourdieu dotyczace pola medialnego Francji lat 70. i 80. XX wieku. Samo pole socjologiczne jest odtworzone bez podania procedury zbierania i analizy danych - wydaje się, że są to po prostu intuicje i spostrzeżenia własne Warczoka i Zaryckiego.

\section{/// Alternatywne założenia - alternatywna rekonstrukcja pola socjologicznego}

Bourdieu stworzył koncepcję pola społecznego w latach 70. XX w. i stosował ją do analiz stosunków społecznych panujących we Francji. Ten sposób konceptualizacji poziomu pośredniego między rzeczywistością poszczególnych aktorów a całym społeczeństwem zainspirował wielu badaczy do stosowania go w innych kontekstach społecznych. Ze względu na narastające napięcia w próbach teoretycznego powiązania poziomów mi- 
kro i makro podobne konceptualizacje poziomu mezo zaczęły pojawiać się równolegle także bez bezpośredniej inspiracji pracami Bourdieu. Przykład teoretycznej syntezy zawierającej również przydatne wskazówki metodologiczne do badania pól społecznych to książka Neila Fligsteina i Douga McAdama A Theory of Fields (2012). Dla nich Bourdieu był źródłem ważnej inspiracji, lecz potraktowany został krytycznie. Autorzy ci wskazali na następujące kruchości w podejściu Bourdieu: (1) skupienie przede wszystkim na jednostkach i zlekceważenie aktorów zbiorowych takich jak organizacje czy grupy społeczne; (2) uproszczona wizja „architektury” pól, na która składają się pozycje wyznaczone dostępem aktorów do władzy; (3) uproszczona wizja relacji między polami - od Bourdieu wiemy, że pola jakoś na siebie wpływaja, ale mechanizm ten nie jest przez niego wyjaśniony; (4) wizja aktora jako zorientowanego tylko na siebie i bezustannie rywalizującego, a nie wchodzącego w sojusze $\mathrm{z}$ innymi aktorami lub działającego w celu poprawy strategicznej pozycji całego pola względem innych pól; (5) statyczna wizja pola, którego zestaw pozycji i dychotomiczne podziały w zasadzie nie poddawane sa zmianie, czy to ze względu na strategiczne działania aktorów w obrębie pola, czy też zdarzenia na zewnątrz powodujące rekonfiguracje wewnątrz pola (Fligstein, McAdam 2012: 24-26).

Te słabości wskazane przez Fligsteina i McAdama w wyjściowej koncepcji Bourdieu pojawiaja się również w jej dogmatycznym zastosowaniu do rzeczywistości Polski drugiej dekady XXI w. zaproponowanym przez Warczoka i Zaryckiego. Odwołując się do Fligsteina i McAdama, a także bliskiej mi koncepcji pola, jaka została wypracowana w obrębie instytucjonalnej socjologii organizacji (szczegółowe jej omówienie zob. Wooten, Hoffman 2008), przedstawię propozycję alternatywnej rekonstrukcji pola socjologicznego w Polsce.

Pole socjologiczne - jako jedno z pól naukowych - jest wysoce zinstytucjonalizowane ${ }^{6}$ i podlega przemianom strukturalnym całości systemu kształcenia wyższego (Kwiek 2014). Analizę reguł gry w nim panujących należałoby rozpocząć od lektury aktów prawnych takich jak Ustawa prawo o sækolnictwie wyisszym, Ustawa o Polskiej Akademii Nank, Ustawa o stopniach $i$ tytule naukowym oraz towarzyszących im rozporządzeń Ministra Nauki i Szkolnictwa Wyższego. Formalne granice pola oraz kapitału naukowego sa tam bardzo ściśle określone. Obecność w polu bez przynależności do organizacji (odpowiedniego instytutu szkoły wyższej lub badawczego) jest prawie niemożliwa - jednostka jest wtedy skazana na marginalizację i wal-

${ }^{6}$ Szczegółowo historię instytucjonalizacji socjologii w Polsce przedstawiła w swoich dwóch książkach Nina Kraśko (1996, 2010). 
kę o utrzymanie się w obrębie granic pola. W ramach tych organizacji istnieją ścisłe hierarchie stanowisk, a podstawą dla miary kapitału naukowego są stopnie od magistra po tytuł profesora. Istotna rolę w polu odgrywaja organizacje nazywane przez Fligsteina i McAdama wewnętrznymi jednostkami zarządzającymi (internal governance units), jakimi są Centralna Komisja do Spraw Stopni i Tytułów Naukowych (CK), Narodowe Centrum Nauki $(\mathrm{NCN})$, Polska Komisja Akredytacyjna (PaKA) ${ }^{7}$. Ciała te z jednej strony sa agendami państwa, ale przedstawiciele poszczególnych dyscyplin cieszą się w nich pewną autonomią, będąc - przynajmniej formalnie - przedstawicielami środowiska, a nie urzędnikami. CK ze względu na ostatnie zmiany w przepisach odgrywa istotną rolę w sankcjonowaniu kapitału naukowego pojedynczych socjologów, natomiast NCN dokonuje konwersji kapitału naukowego na kapitał faktyczny, dystrybuując do uczelni środki na badania. Wreszcie PaKA certyfikuje możliwość prowadzenia studiów socjologicznych, posiada więc prawo wykluczania organizacji z obrębu pola.

Formalne ramy określające reguły gry w polu socjologicznym w efekcie prowadzonej obecnie reformy nauki przechodzą zmiany powodujące stan niepewności. Zmieniono pewne reguły konwersji kapitału naukowego na kapitał faktyczny, np. pojawiła się presja na publikacje w międzynarodowych czasopismach. Zmniejszono zakres uznaniowości organizacyjnych uczestników pola w nadawaniu stopni naukowych sankcjonujących kapital naukowy. Jest to jeden ze wstrząsów zewnętrznych wpływających na sytuację w polu socjologicznym. Jego siła wpływu wynika z zależności pola od państwa - większość środków na prowadzenie nauczania socjologii pochodzi z dotacji dydaktycznej ministerstwa przekazywanej tylko jednostkom uzyskującym akredytację. Większość środków przyznawanych na badania pochodzi również od państwa.

„Zasobem” wykorzystywanym przez pole socjologiczne są również studenci. Chętni do studiowania na studiach stacjonarnych na uczelniach publicznych pozwalają na pozyskiwanie dotacji dydaktycznej. Chętni do studiowania na studiach niestacjonarnych i uczelniach prywatnych, opłacając czesne, bezpośrednio przynoszą kapitał faktyczny. Wynikające z niżu demograficznego oraz relatywnego obniżenia popularności studiów socjologicznych wobec innych kierunków zmniejszenie liczby kandydatów jest kolejnym ważnym czynnikiem zewnętrznym wpływającym na pole socjologiczne. W efekcie przestało istnieć wiele uczelni prywatnych oferujących studia socjologiczne, a nawet instytuty socjologii uczelni publicznych stoja

\footnotetext{
${ }^{7} \mathrm{Na}$ boku pozostawiam ciekawe pytania, na ile rolę taką pełni Polskie Towarzystwo Socjologiczne oraz Komitet Socjologii PAN?
} 
przed perspektywą obniżenia liczby studiujących. Widać zatem jednoczesny wpływ na aktorów organizacyjnych i jednostkowych. W tej pierwszej kategorii niektórzy po prostu przestali istnieć. Natomiast pojedynczy socjologowie bądź utracili miejsce pierwszego zatrudnienia, wypadając tym samym poza obręb pola, bądź stracili możliwość uzyskania dodatkowego dochodu. Część instytutów socjologicznych, jeśli posiada takie uprawnienia, prowadzi szeroką dydaktykę na studiach doktoranckich, co ma być częściowo odpowiedzią na niedobór studentów poziomu licencjatu i magisterium (pięciokrotnie większa dotacja na studenta studiów III stopnia niż stopnia I lub II!). Jednak w konsekwencji produkowanych jest wielu nowych kandydatów do zajęcia pozycji w obrębie pola.

Dodatkowy dochód możliwy jest do uzyskania również w ramach różnego rodzaju aktywności ekspercko-badawczej finansowanej zarówno przez rynek, jak i różnorakie instytucje publiczne (od centralnych po samorządowe). Ta forma uprawiania socjologii praktycznej, zgodnie z przyjętymi przeze mnie założeniami, tworzy już odmienne pole rynkowych usług badawczych. Leży ono blisko pola socjologicznego, jednak obowiązuje w nim odmienna logika. Kapitał naukowy przeniesiony z pola socjologicznego bywa w tej działalności przydatny, jednak nie jest niezbędny.

Oczywiście naiwnościa byłoby odtwarzanie reguł panujących w polu tylko na postawie lektury aktów prawnych. Na poziomie poszczególnych organizacji, czyli wydziałów czy instytutów zatrudniających socjologów wiele zależy od niesformalizowanego wpływu i różnorakich działań zakulisowych, które mogłyby być tematem do fascynującej analizy à la Zybertowicz. Mamy także (podejmowane przez posiadających władzę aktorów) dokonywanie przekładów reguł formalnych na praktykę codziennego postępowania. Środowisko uwielbia plotkować o tzw. „grupach trzymających władzę” w poszczególnych radach naukowych, sterowalności „merytoryczną" oceną dorobku naukowego czy podejmowaniu decyzji niezgodnych z przepisami, których prawomocności nikt otwarcie nie decyduje się kwestionować itd. Również relacje międzyorganizacyjne mogłyby być obszarem podobnych dociekań: zwłaszcza dotyczyć by one mogły tego, jaki jest wpływ przedstawicieli kluczowych aktorów organizacyjnych na decyzje podejmowane przez wewnętrzne jednostki zarządzające CK, NCN i PaKA i na ile określane tam reguły przynoszą korzyści jednym aktorom, jednocześnie defaworyzując innych.

Należałoby prześledzić relacje pola socjologicznego z innymi polami. Widać już, że jest ono bardzo zależne od szeroko pojętej administracji rządowej, którą Fligstein i McAdam nakazują również analizować jako skompli- 
kowane pole (2012). Ważne byłoby prześledzenie relacji z polami, w których socjologowie moga poszukiwać źródeł dodatkowego dochodu - czyli polem szeroko pojętych badań na potrzeby rynku (od badań opinii publicznej po badania konsumenckie) oraz polem usług badawczych zlecanych przez agendy publiczne, ale innymi kanałami niż środki na badania „naukowe” - moga w nich uczestniczyć również firmy, organizacje pozarządowe, ale również i uczelnie. Kolejne pola, których relacje do pola socjologicznego należałoby prześledzić, to inne pola naukowe, które mogą stanowić niebezpieczną konkurencję - jak wydaje się być obecnie z polem psychologicznym. Interesujące jest rozstrzygnięcie kwestii relacji pola socjologicznego z polem medialnym. Jakiego rodzaju kapitał przynosi socjologom obecność w mediach? Jak przekłada się na ich kapitał naukowy, a jak na faktyczny?

Ostatnie pytanie, na które warto byłoby odpowiedzieć, dotyczy efektów obecności przedstawicieli pola socjologicznego w polu władzy. Poza przedstawicielami prawoznawstwa i nauk ekonomicznych, których uczestnictwo w ważnych instytucjach państwowych jest silnie zinstytucjonalizowane (np. Trybunał Konstytucyjny lub Rada Polityki Pieniężnej), profesorowie socjologii zajmują obecnie pozycje: Ministra Nauki i Szkolnictwa Wyższego, Wicemarszałka Senatu oraz Pełnomocnika Rządu ds. Równouprawnienia. $Z$ przeciwnej strony podziałów politycznych do niedawna profesor socjologii był głównym kandydatem opozycji na premiera ${ }^{8}$.

Przyjąłem odmienne niż Warczok i Zarycki założenia, rekonstruując pole socjologiczne, $i$ w konsekwencji uzyskałem inny jego obraz. Kluczowe wydaja się w nim nie relacje wobec pola medialnego i mętnie określonego pola władzy, lecz pozycje w strukturach organizacyjnych, bez pośrednictwa których uprawianie nauki w Polsce jest prawie niemożliwe. Dysponujemy szeregiem zinstytucjonalizowanych miar kapitału naukowego (stopnie naukowe, oceny parametryczne jednostek, miary poziomu i liczby publikacji itd.) oraz nieformalnego prestiżu, z których wyłania się nie dychotomiczny, lecz raczej rangowy (i tak przy założeniu, że da się go wyrazić w jednym wymiarze) układ hierarchii. Ważną cechą tego układu jest to, że nie są one przypisane: istnieje zinstytucjonalizowana ścieżka awansu naukowego, a transfery między organizacjami, chociaż w Polsce stosunkowo rzadkie, również mają miejsce. Istnieje zatem zakres możliwości dla działania strategicznego: wykorzystania przemian zachodzących zewnętrznie wobec pola, zdefiniowania na swoją korzyść niejasnych lub sprzecznych reguł instytucjonalnych oraz promowania posiadanych przez siebie zasobów jako istotnych dla wymierzenia kapitału naukowego. Istnieje równolegle zakres

${ }_{8}^{8}$ Tekst powstał przed wyborami parlamentarnymi w 2015 roku. 
wykluczenia i relacji podległości niedostrzeżony przez Warczoka i Zaryckiego, który nie jest związany z odtwarzaniem podziałów w polu władzy, lecz struktura organizacyjna, w ramach której uprawiana jest socjologia: obecne miejsca pracy są zagrożone ze względu na zmniejszenie „dopływu” studentów, zredefiniowane miary kapitału naukowego są niekorzystne dla części obecnych w polu (np. tzw. „zasłużeni dydaktycy”), wreszcie pole produkuje liczne grono kandydatów do uczestnictwa (doktorantów), których szanse na zajęcie pozycji w nim maleją. Można powiedzieć, że te relacje dominacji pozostaja przez Warczoka i Zaryckiego ukryte.

\section{/// W pułapce zwrotności}

Uprawiając socjologię socjologii, wpada się w paradoksalną sytuację zwrotności. Badacz odnosi się do pola, w którym zajmuje pozycję i stosuje do opisu swojej grupy kategorie zwykle stosowane do opisu innych - bada sam siebie, będąc jednocześnie insiderem i outsiderem (Ashmore 1989). Ten, kto to czyni, musi pogodzić się z tym, że i on na kolejnym poziomie analizy - socjologii socjologii socjologii - również poddany zostanie badaniu. Stosując zaproponowany przeze mnie alternatywny zestaw założeń dotyczących struktury pola socjologicznego w Polsce, przedstawię teraz interpretację tekstów Warczoka i Zaryckiego jako działania strategicznego.

Część wypowiedzi Warczoka i Zaryckiego na temat innych socjologów można łatwo przedstawić jako dotyczące również ich samych. Dla przykładu stwierdzenie „Niezależnie [...] od tego, że socjologowie dysponuja w zasadzie tylko opiniami badanych na temat rzeczywistości, nie wahają się przed kwalifikowaniem ich jako słusznych bądź też fałszywych, tak jakby byli w posiadaniu także prawdy o tej rzeczywistości, choć nie bardzo wiadomo, w jaki sposób stała się ona im dostępna" (Warczok, Zarycki 2014a: 143, cyt. za Bukraba-Rylska 2004: 158), można również odnieść do autorów, którzy kwalifikują sądy innych socjologów jako słuszne, niesłuszne, wynikające z nieświadomości, jednocześnie samemu starających się przekonać, że dostępna jest im prawda o rzeczywistości. Ich zdaniem „opisani socjologowie dokonuja aktu legitymizacji z pozycji i pod pozorem nauki”" (Warczok, Zarycki 2014a: 147), jednak przecież sami autorzy dokonują aktów legitymizacji i delegitymizacji, a wszak naukowość ich rozważań również można łatwo kwestionować - np. wskazując na niedostatki metodologiczne i dogmatyzm w traktowaniu głównej ramy teoretycznej - i przypisywać jej etykietę pozoru. 
W swoim tekście Bourdieu recontextualized Warczok i Zarycki (2014b) eksplorują fascynujący paradoks wykorzystania koncepcji kapitału kulturowego do legitymizacji status quo, a nie do jego krytyki, co było intencją Bourdieu. Sami jednak dokonuja podobnie paradoksalnej wolty, gdy używają obycia z teorią Bourdieu jako kryterium oceny innych w polu. Znajomość myśli Bourdieu określona zostaje jako kapitał, dzięki któremu można być uznanym za „prawdziwego” socjologa. Zgodnie z koncepcja Bourdieu to uprzywilejowani definiuja, co jest kapitałem. Gdy zbyt wielu konkurentów potrafi posługiwać się jego pojęciami, konieczne staje się przesunięcie dystynkcji i stwierdzenie, że nie dokonują tego zgodnie z krytyczną intencją mistrza. Warczok i Zarycki starają się wykorzystać zasób, który posiadają, i zdefiniować go jako istotny kapitał. Mianuja się w ten sposób arbitrami smaku i rozdzielają oceny z biegłości w teorii Bourdieu: Henryk Domański, Wojciech Broszkiewicz i Adam Bartoszek otrzymują naganę, ale za to Maciej Gdula i Przemysław Sadura pochwałę.

Jednocześnie autorzy przedstawiają siebie jako zajmujących pozycje strukturalnie zdominowane w polu, jednak odseparowane od jego głównej dychotomii (co jest zaprzeczeniem przyjętych założeń!), uprawniająca ich do krytyki. Postawienie jako naczelnego problemu w polu jego zależności od podziałów narzucanych przez pole władzy oraz pole medialne powoduje przykrycie relacji władzy, które stają się możliwe do uchwycenia przy przyjęciu założeń mówiących, że pole strukturowane jest przede wszystkim przez umiejscowione w nim organizacje. Anihilacja uczelni prywatnych zatrudniających rzeszę socjologów, niepewna sytuacja pracownicza kadry naukowo-dydaktycznej nieposiadającej habilitacji czy nierówny dostęp do zasobów finansowych dystrybuowanych w ramach „merytorycznej” oceny wniosków grantowych stają się niewidoczne. Oczywiście, należy podkreślić i za autorami przypomnieć, że zdominowani w polu socjologicznym w strukturze szans dostępnych członkom społeczeństwa polskiego stoja bardzo wysoko. Jednak wymiar status quo, w którym autorzy zdają się zajmować uprzywilejowane pozycje, nie jest w ogóle przez nich krytycznie tematyzowany.

Wydaje się to dobra ilustracją do tezy Fligsteina i McAdama (2012), że niezależnie od rozkładu zasobów i pozycji w polu rozgrywaja się ciagłe podchody (jockeying), w których strategicznie działający aktorzy poszukuja okazji do zyskania nawet drobnej przewagi nad innymi. Za przykład takiego działania strategicznego należy uznać wystąpienie Warczoka i Zaryckiego: jest to próba wzmocnienia własnej pozycji w polu i osłabienia pozycji 
w polu zajmowanych przez innych graczy; za istotny kapitał uważane jest obycie z teorią Bourdieu.

\section{/// Socjologia krytyczna i demaskatorska}

Warczok i Zarycki w podsumowaniu swojego tekstu piszą, że „główną zatem przeszkodą w rozwoju myśli krytycznej i realnie krytycznego zaangażowania się polskich socjologów wydaje się przede wszystkim ograniczona neutralność pola socjologicznego" (2014a: 152). Jak wnioskują autorzy, gdyby pole socjologiczne było bardziej autonomiczne, a socjologowie mieliby więcej czasu, to byliby w stanie w rzeczywisty sposób skuteczniej demaskować relacje władzy w społeczeństwie polskim. Sądzę, że autonomia pola socjologicznego (i jakiegokolwiek pola) jest ułudą. Cechą późnonowoczesnego świata jest wielość wzajemnie na siebie wpływających pól oraz to, że zdecydowana większość aktywności dokonywana jest za pośrednictwem organizacji (Fligstein, McAdam 2012, Meyer, Bromley 2013). Pole socjologiczne jest w Polsce zależne od państwa w stopniu nie mniejszym niż we Francji, która wydała Bourdieu. Paradoksalnie jego zależność od rynku - wraz z upadkiem przemysłu masowej edukacji socjologicznej na prywatnych uczelniach - obecnie nawet spadła. Czy na pewno autonomia pola, dając socjologom więcej czasu, pozwoliłaby im uprawiać prawdziwie demaskatorską naukę? Jak stworzyć mechanizm zachowujący równowagę między autonomią a presją instytucjonalną niepozwalającą na marnotrawienie czasu?

Idąc za Burawoyem (2009), którego koncepcja socjologii publicznej była ważną inspiracją dla Warczoka i Zaryckiego, proponowałbym doszukiwać się słabości socjologii demaskatorskiej w specyfice relacji pomiędzy czterema typami socjologii oraz w defektach socjologii akademickiej. Ale do tego konieczne jest dokładne odczytanie manifestu Burawoya i poważne potraktowanie jego tez.

Zacznijmy od socjologii publicznej zdefiniowanej przez Burawoya jako taka, która „skłania socjologię do rozmowy z publicznością, czyli ludźmi, którzy sami zaangażowani są w rozmowę" (2009: 530). Burawoy wyróżnia jej dwa zasadnicze podtypy: tradycyjny i organiczny. Tradycyjna socjologia publiczna to komentarz socjologów do istotnych kwestii publicznych, włączenie się do debaty na temat tego, co jest obecnie interesujące dla większości. Ten podtyp socjologii publicznej Warczok i Zarycki śledzili, przyglądając się aktywności prominentnych socjologów w ogólnokrajowych mediach. Jednak zlekceważyli organiczną socjologię publiczną, „w ramach której so- 
cjologowie pracują w bliskiej relacji z widoczną, gęstą, aktywną, lokalną i często stojącą w opozycji wobec głównego nurtu społeczeństwa, publicznością" (Burawoy 2009: 530), czyli aktywność socjologów w debatach nie toczonych w mediach, dotyczących kwestii szczegółowych, na przykład przy okazji konsultacji społecznych projektów ustaw czy przy ujawnieniu dzięki wynikom badań nieefektywności instytucji publicznych. Organiczna socjologia publiczna ma w sobie potencjał demaskatorski i może (dotyczy to również tradycyjnej socjologii publicznej) służyć krytyce relacji władzy w społeczeństwie. Za przykład takiej aktywności socjologów posłużyć może stosunkowo wąski obszar badań nad imigracją do Polski, gdzie jak wynika z moich analiz, socjologowie i przedstawiciele innych pokrewnych dyscyplin w sposób bardzo krytyczny analizują aktywność agend rządowych i wywieraja presję przyczyniająca się m.in. do poprawy warunków w ośrodkach dla uchodźców czy poprawy prowadzonej polityki integracji (Pawlak 2012). Analiza uczestnictwa socjologów w wielu innych debatach dotyczących różnego rodzaju problemów społecznych tylko incydentalnie cieszących się uznaniem mediów głównego nurtu jest zadaniem wartym podjęcia badań. Przede wszystkim interesujące byłoby oszacowanie wpływu, jaki mają badacze społeczni na zmianę danej sytuacji. Kolejnym zadaniem byłoby prześledzenie tego, na ile rola socjologii publicznej jest w tych przypadkach powiązana z rola socjologii praktycznej. W badanym przeze mnie obszarze studiów nad imigracja podstawą do krytyki aktualnego stanu rzeczy były wyniki badań o charakterze eksperckim finansowanych przez instytucje publiczne. Jak zwraca się uwagę w tradycji analiz stosowania nauk społecznych, poza możliwością wykorzystania wyników badań w sposób instrumentalny (bezpośrednie przełożenie na działalność decydentów) lub symboliczny (w celu legitymizacji działań decydentów faktycznie nieprzejmujących się wynikami badań) długotrwałym skutkiem jest ich wpływ objaśniający - zmieniający dyskurs i kategorie postrzegania danego problemu (Frieske 1990).

To, co zostało dobrze udokumentowane przez Warczoka i Zaryckiego, to określana przez Burawoya jako patologia socjologii publicznej tendencja do zabiegania o popularność, skutkiem której socjologowie ulegaja ,„pokusie dogadzania i schlebiania swoim publicznościom” lub wręcz ida jeszcze dalej i zaczynaja „przemawiać językiem swoich publiczności jako rodzaj ich intelektualnej awangardy" (Burawoy 2009: 545). Burawoy określa to jako sprzeniewierzenie się akademickim i krytycznym zobowiązaniom. Tak bym postrzegal przytaczane przez Warczoka i Zaryckiego wypowiedzi socjologów, którzy schlebiaja poszczególnym kategoriom społecznym 
w Polsce. Trzymając się uproszczonego podziału na wygranych i przegranych transformacji, procentrowa część z wymienionych przez Warczoka i Zaryckiego badaczy wyjaśnia „wygranym”, czemu odnieśli sukces, i daje im powód do dystansowania się od „przegranych”. Natomiast socjologowie antycentrowi schlebiają „przegranym”, wyjaśniając im, w jaki sposób „wygrani” ich oszukali. Rzeczywiście, jedni i drudzy przemawiaja językiem swojej publiczności, stając się częścią jej intelektualnej awangardy, a nie stawiając w debacie publicznej nowe pytania.

Socjologia praktyczna została przez Warczoka i Zaryckiego potraktowana po macoszemu - prawdą jest, że Burawoya też najmniej ona interesuje. Jednak Warczok i Zarycki wypowiadają się o niej z pogarda, nazywając ją służebna, czyli zajęciem niegodnym inteligenta. W Polsce mamy silne tradycje socjologii praktycznej, której chyba największym osiąnnięciem była koncepcja socjotechniki (Podgórecki 1966). Od czasu książki Kazimierza Frieske na temat nadziei i rozczarowań związanych ze stosowaniem socjologii (1990) nie ukazała się chyba żadna praca dokonująca syntezy wykorzystania praktycznego socjologii w Polsce. Sądzę, że pytanie, na ile wiedza empiryczna zebrana w badaniach praktycznych - na przykład prężnie rozwijającej się ewaluacji - dostarcza materiału dla rozwoju socjologii akademickiej, pozostaje otwarte?. Warczok i Zarycki przyjęli, że tego typu aktywność jest niewiele warta i służy przede wszystkim osiaganiu przez socjologów dodatkowych dochodów. Określenie „służebna” wskazuje, że rozumieja ją w najprostszym sensie, który Podgórecki nazywał „inżynieryjnym" - socjolog bezrefleksyjnie wykonuje zamówienie badawcze zlecone przez decydenta. Jednak rolę badacza w relacji z decydentem można rozumieć jeszcze w sensie „klinicznym” - wtedy ich współpraca nosi charakter dialogu, a socjolog ponosi współodpowiedzialność za wykorzystanie swojej wiedzy praktycznej - bądź w sensie „ekspertalno-interwencyjnym” wtedy badacz pierwszy wychodzi z inicjatywą przeprowadzenia społecznie użytecznych reform ${ }^{10}$ (Podgórecki 1966). Podsumowując, kwestia socjologii praktycznej w Polsce nie jest taka prosta, jak widzą ją Warczok i Zarycki, i z pewnością oczekuje na metaanalizę, na podstawie której dopiero będzie można wyciągać wnioski dotyczące jej kondycji.

\footnotetext{
${ }_{9}$ Analiza taka dotyczyć by musiała również ciekawej kwestii relacji między polem socjologicznym a oddzielnym polem różnego rodzaju badań usługowych.

${ }^{10}$ Socjotechnikę w sensie ekspertalno-interwencyjnym w koncepcji Burawoya umieścić należałoby raczej już w socjologii publicznej. Zderzenie tych dwóch typologii funkcji socjologii pokazuje, jak bardzo każda z funkcji czy typów socjologii jest ze sobą powiązana, a tworzenie takich rozróżnień ma charakter wyłącznie analityczny. Sam Burawoy również podkreślał, że wymienione przez niego cztery typy socjologii są typami idealnymi, a zwłaszcza granica między socjologią publiczną i praktyczną często się zaciera (2009: 536).
} 
Socjologia krytyczna w rozumieniu Burawoya ma - przypomnijmy dokonywać analizy ,założeń programów badawczych realizowanych w ramach socjologii akademickiej - zarówno jawnych, jak i ukrytych, normatywnych, jak i deskryptywnych" (2009: 535). W tym sensie artykuł Warczoka i Zaryckiego jest przykładem socjologii krytycznej, jednak autorzy ci posługują się w nim jeszcze znaczeniem tego terminu zaczerpniętym z tradycji teorii krytycznej i za Bourdieu rozumieją socjologię krytyczna jako demistyfikująca relacje władzy. W tym sensie Burawoy zakwalifikowałby ich ujęcie socjologii krytycznej do socjologii publicznej. Pisząc o socjologii krytycznej, Burawoy podkreślał, że jej istnienie jest konieczne dla rozwoju socjologii akademickiej. Jednak wskazywał również na zagrożenie patologia sekciarstwa - wytwarzania się ,wspólnot dogmy, które nie mają ani żadnych poważnych zobowiązań wobec socjologii akademickiej, ani nie wnoszą nic wartościowego do socjologii publicznej” (Burawoy 2009: 544). Ten krótki passus dotyczący dogmatyzmu jest trafnym podsumowaniem pułapki, w którą wpadli Warczok i Zarycki. Ich krytyka obecnych w mediach polskich socjologów, choć miejscami niezwykle trafna, przybrała karykaturalną formę oceny za spełnienie kryteriów wyznaczonych przez bourdiańską dogmę.

Za serce socjologii jednak Burawoy uznaje socjologię akademicka i moim zdaniem w jej słabościach należy doszukiwać się ograniczeń dla demaskatorskiego potencjału socjologii zaangażowanej w demistyfikację istniejących relacji władzy. Kwestii tej poświęcam kolejną część niniejszego tekstu.

\section{/// Przeciwko socjologii eseistycznej}

W 1986 roku podczas Zjazdu Socjologicznego we Wrocławiu Antoni Sułek, analizując kondycję ówczesnej socjologii polskiej, stwierdził, że ma ona charakter oralny (1987). Oznacza to, że wyniki badań były wówczas komunikowane przede wszystkim podczas konferencji i wystapień na zebraniach naukowych. Mało z nich przybierało ostateczną formę publikacji jako artykuły lub książki. Sułek podawał przyczyny zewnętrzne, jakimi były cenzura i długi cykl wydawniczy. Jednak za najważniejsze uważał powody wewnętrzne - brak zinstytucjonalizowanej presji na publikowanie osiagnięć badań socjologicznych przy równoczesnym zdobywaniu prestiżu naukowego na podstawie wystąpień ustnych. Sułek krytykował ten stan, tytułując swoje wystapienie Przecinko socjologii „oralnej"11.

11 Co ciekawe, w pamięci socjologów zachowało się określenie „,socjologia oralna”, ale już nie to, że Sułek był jej zdecydowanym krytykiem. 
Blisko 30 lat po wystapieniu Sułka warunki uprawiania socjologii w Polsce są całkowicie zmienione. Nie ma przeszkód zewnętrznych w publikowaniu, natomiast brak wewnętrznej presji zamienił się w silny przymus ogłaszania drukiem tekstów, których socjologia akademicka produkuje w ilości niemożliwej do ogarnięcia. W moim studium poświęconym wykorzystaniu koncepcji „próżni socjologicznej” dokonałem analizy blisko dwustu publikacji socjologicznych (Pawlak 2015). Uderza to, jak wiele z nich przyjmuje formę eseju, czyli gatunku literackiego otwartego, operującego barwnym obrazowaniem i metaforyka, w którym dominuje podmiotowy punkt widzenia, filtrujący badane zjawiska poprzez psychikę i intuicję autora (Wroczyński 1986). Pisząc eseje dotyczące zjawisk społecznych w Polsce, socjologowie dramatyzują swoje narracje, używają naładowanych emocjami pojęć, niekoniecznie dbając przy okazji o przeprowadzenie zdyscyplinowanego przeglądu literatury tematu oraz prezentację swojego warsztatu badawczego - o ile teksty te odnoszą się do badań własnych, a nie przedstawiają tylko refleksji dotyczących badań cudzych i kwestii teoretycznych. W eseju można powiedzieć „więcej”, czyli celowo wyostrza się $\mathrm{w}$ nim pewne tezy i stylizuje informacje pochodzące $z$ danych empirycznych. Stosowane w nim wyjaśnienia maja charakter retoryczny - liczy się bardziej chwyt literacki niż odwołanie do rzeczywistości zewnętrznej. Zwracam uwagę, że te cechy nosi również omawiany tutaj tekst Warczoka i Zaryckiego, ale również większość - poza pracami Henryka Domańskiego - analizowanych przez nich publikacji socjologicznych.

Skutkiem nadmiernego wykorzystania gatunku eseju wiedza socjologiczna o społeczeństwie polskim ${ }^{12}$ jest udramatyzowana, przesadzona, a czasem nawet niewiarygodna. Czy oznacza to, że mamy odrzucić esej socjologiczny jako sposób komunikacji? Oczywiście, że nie jestem zwolennikiem takiego absurdalnego rozwiązania. Esej, który ma raczej stawiać pytania, niż dawać na nie ostateczne odpowiedzi, oraz inspirować dyskusje, a nie wyjaśniać świat, jest potrzebną formą wyrazu zwłaszcza dla socjologii publicznej i niekiedy krytycznej. Może być także punktem wyjścia do empirycznej weryfikacji postawionych diagnoz. W takim ujęciu gatunkami literackimi odpowiednimi dla socjologii praktycznej byłby raport badawczy zawierający rekomendacje, natomiast dla socjologii akademickiej - artykuł naukowy zawierający omówienie literatury tematu, prezentację procedury badawczej, analizę danych i dyskusję uzyskanych wyników. Do napisania dobrego eseju trzeba mistrzostwa, jednak esej nie wymaga tego, co cha-

${ }^{12}$ W niniejszym tekście koncentruję się polskim polu socjologicznym, jednak socjologia eseistyczna uprawiana jest $\mathrm{i} w$ innych krajach. 
rakteryzuje rzetelny artykuł: zdyscyplinowanego i krytycznego przestudiowania literatury tematu (w eseju cytowanie ma charakter dowolny) oraz przedstawienia wyników badań. W tym sensie esej bywa mniej wymagający od autora niż artykuł. Co więcej, esej jest gatunkiem niekrytykowalnym posługuje się metaforą i wyostrzeniem. Zatem jeśli komuś się nie podoba, to uznać to należy za kwestię smaku lub braku zrozumienia.

Z mojej analizy socjologicznych tekstów odwołujących się do koncepcji „próżni socjologicznej” wynika, że esej jest w polskiej socjologii gatunkiem bardzo popularnym. Może wynika to z tego, że tak wielu socjologów pragnie być socjologami publicznymi lub krytycznymi, a nie nudnymi przedstawicielami socjologii akademickiej? Jeżeli tak wielu socjologów pragnie być socjologami publicznymi lub krytycznymi, to przyczynić się to musi do osłabienia socjologii akademickiej, o której Burawoy pisze, że „sercem naszej dyscypliny jest jej komponent akademicki. Bez socjologii akademickiej nie może istnieć socjologia praktyczna czy socjologia publiczna, ale i socjologia krytyczna, ponieważ nie miałaby czego krytykować” (Burawoy 2009: 543). Efektem zwrotnym musi być słabość samej socjologii publicznej i krytycznej, które zjadają własne podstawy, często nimi gardząc.

Jakie sa strukturalne przyczyny takiej sytuacji? Odpowiedzi udzielić mogą tylko badania z zakresu socjologii socjologii, zwłaszcza uwzględniające organizacyjne i instytucjonalne warunki jej uprawiania. Podstawowy domysł jest taki, że wynika to z instytucjonalnej presji na publikowanie przy niskiej instytucjonalizacji kontroli jakości publikacji. Kolejny kierunek dla poszukiwań odpowiedzi - zgodny, jak sądzę, z poglądami Warczoka i Zaryckiego - wskazywałby na to, że socjologia w Polsce jest formą aktywności inteligenckiej. Socjolog to przede wszystkim inteligent korzystający z dyskursu socjologicznego, aby przedstawić swoje stanowisko wobec spraw polskich. W związku z tym niekoniecznie atrakcyjne jest dla niego żmudne warsztatowo (rzemieślnicze) prowadzenie badań i ogłaszanie ich wyników w zestandaryzowanej, nudnej formie. Socjolog inteligent pragnie wypowiadać się w ważnych sprawach publicznych i krytykować, krytykować... Esej socjologiczny jest tu świetnym narzędziem - nosi znamiona naukowości, ale równocześnie pozwala wprowadzać treści silnie normatywne, mieszać to, jak sprawy się mają, z tym, jak mieć się powinny. Dla półperyferyjnego inteligentna o postawie pałubicznej (Podgórecki 1995) wartością jest zatem gest, widowisko, a nie przedstawienie lub rozwiązanie problemu: ważniejsze jest popisanie się znajomościa prac francuskiego mistrza niż wiedza empiryczna na temat własnego środowiska lokalnego. 
Bibliografia:

/// Ashmore M. 1989. The Reflexive Thesis. Wrighting Sociology of Scientific Knowledge, The University of Chicago Press, Chicago.

/// Bukraba-Rylska I. 2004. Socjolog czasu transformacji-portret ₹oddali, [w:] Zmiana czy stagnacja, red. M. Marody, Wydawnictwo Naukowe Scholar, Warszawa, s. 153-174.

/// Burawoy M. 2009. O socjologie publiczna. Przemówienie preaydenckie z roku 2004, tłum. A. Dziuban, [w:] Nowe perspektymy teorii socjologicznej, red. A. Manterys, J. Mucha, Nomos, Kraków, s. 525-561.

/// Fligstein N., McAdam D. 2012. A Theory of Fields, Oxford University Press, New York.

/// Frieske K.W. 1990. Socjologia w driałaniu. Nadzieje i rozcrarowania, Wydawnictwa Uniwersytetu Warszawskiego, Warszawa.

/// Kraśko N. 1996. Instytucjonalizacja socjologii w Polsce 1920-1970, Wydawnictwo Naukowe PWN, Warszawa.

/// Kraśko N. 2010. Instytucjonalizacja socjologii w Polsce 1970-2000, Wydawnictwa Uniwersytetu Warszawskiego, Warszawa.

/// Kwiek M. 2014. Structural changes in the Polish bigher education system (1990-2010). A synthetic view, „European Journal of Higher Education”, vol. 4, no. 3, s. 266-280.

/// Marody M., red. 1991. Co nam zostało z tych lat? Spoteczeństwo polskie u progu zmiany systemowej, Aneks, Londyn.

/// Meyer J.W., Bromley P. 2013. The worldwide expansion of "organization", „Sociological Theory”, vol. 31, issue 4, s. 366-389.

/// Pawlak M. 2012. Asymetrie i klisze pojeciowe w analizach uchodźstwa w Polsce, „Studia Migracyjne - Przegląd Polonijny”, nr 38, z. 2, s. 163-185.

/// Pawlak M. 2015. From Sociological Vacuum to Horror Vacui. How Stefan Nowak's Thesis is Used in Analyses of Polish Society, „Polish Sociological Review", nr 1(189), s. 5-27.

/// Podgórecki A. 1966. Pię́́ funkcji socjologii, „Studia Socjologiczne”, nr 3(22), s. 221-243. 
/// Podgórecki A. 1995. Społeczenéstwo polskie, Wydawnictwo Wyższej Szkoły Pedagogicznej, Rzeszów.

/// Sułek A. 1987. Prz̧eciwko socjologii ,oralnej”, [w:] VII Ogólnopolski Zjaz̨ Socjologiczny. Materiaty, red. E. Wnuk-Lipiński, Polskie Towarzystwo Socjologiczne, Warszawa, s. 199-204.

/// Sztompka P. 1993. Civilizational Incompetence. The Trap of Post-Communist Societies, „Zeitschrift für Soziologie”, Jg. 22, H. 2, s. 85-95.

/// Wallerstein I. 1974. The Modern World System. Capitalist Agriculture and the Origins of the European World Economy in the Sixteenth Century, Academic Press, New York.

/// Warczok T., Zarycki T. 2014a. (Ukryte) zaangażowanie i (pozorna) neutralność. Strukturalne ograniczenia roz̧woju socjologii krytycznej w warunkach pótperyferyjnych, „Stan Rzeczy”, nr 6, s. 129-158.

/// Warczok T., Zarycki T. 2014b. Bourdieu recontextualized. Redefinitions of western critical thought in the periphery, "Current Sociology”, nr 62(3), s. 334-351.

/// Wroczyński T. 1986. Esej - zarys teorii gatunku, „Przegląd Humanistyczny", nr 5-6, s. 101-113.

/// Wooten M., Hoffman A.J. 2008. Organizational Fields. Past, Present and Future, [w:] The SAGE Handbook of Organizational Institutionalism, red. R. Greenwood i in., SAGE Publications, Los Angeles, s. 130-147.

\section{/// Abstrakt}

Do zrozumienia stanu socjologii krytycznej konieczna jest rekonstrukcja pola socjologicznego, w którym jest ona wytwarzana, oraz jej relacji z socjologia akademicka, praktyczną i publiczną. W artykule przedstawiona jest alternatywna wobec zaproponowanej przez T. Warczoka i T. Zaryckiego rekonstrukcja pola socjologicznego w Polsce, a ich wystąpienie interpretowane jest jako działanie strategicznych aktorów. Ograniczenia socjologii krytycznej upatrywane są w słabościach socjologii akademickiej, która - często korzystając z gatunku eseju - wiedzę o polskim społeczeństwie przedstawia w sposób silnie udramatyzowany. 
Słowa kluczowe:

esej, pole społeczne, socjologia akademicka, socjologia krytyczna, socjologia publiczna

\section{/// Abstract}

In order to understand how matters currently stand in critical sociology, the field of sociology, in which this critical discourse is produced, as well as its relations to professional, policy and public sociologies should be reconstructed. This article presents an alternative perspective to the one proposed by T. Warczok and T. Zarycki's reconstruction of the field of sociology in Poland, their paper being interpreted as an action by strategic actors. This paper traces the limitations of critical sociology to the weaknesses of professional sociology, which often uses an essayistic genre and presents the knowledge on Polish society in a highly dramatized manner.

Keywords:

essay, social field, professional sociology, critical sociology, public sociology 